Prepared in cooperation with the Idaho Department of Environmental Quality

\title{
Compilation and Analysis of Multiple Groundwater-Quality Datasets for Idaho
}

Open-File Report 2018-1079 


\section{Compilation and Analysis of Multiple Groundwater-Quality Datasets for Idaho}

By Stephen A. Hundt and Candice B. Hopkins

Prepared in cooperation with the Idaho Department of Environmental Quality

Open-File Report 2018-1079

U.S. Department of the Interior

U.S. Geological Survey 


\section{U.S. Department of the Interior \\ RYAN K. ZINKE, Secretary}

\section{U.S. Geological Survey \\ William H. Werkheiser, Deputy Director \\ exercising the authority of the Director}

U.S. Geological Survey, Reston, Virginia: 2018

For more information on the USGS-the Federal source for science about the Earth,
its natural and living resources, natural hazards, and the environment-visit
https://www.usgs.gov/ or call 1-888-ASK-USGS (1-888-275-8747).
For an overview of USGS information products, including maps, imagery, and publications,
visit https://store.usgs.gov/.

Any use of trade, firm, or product names is for descriptive purposes only and does not imply endorsement by the U.S. Government.

Although this information product, for the most part, is in the public domain, it also may contain copyrighted materials as noted in the text. Permission to reproduce copyrighted items must be secured from the copyright owner.

Suggested citation:

Hundt, S.A., and Hopkins, C.B., 2018, Compilation and analysis of multiple groundwater-quality datasets for Idaho: U.S. Geological Survey Open-File Report 2018-1079, 3 p., plus presentation, https://doi.org/10.3133/ofr20181079.

ISSN 2331-1258 (online) 
Contents

Abstract.

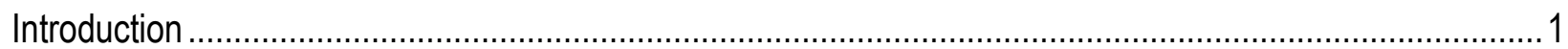

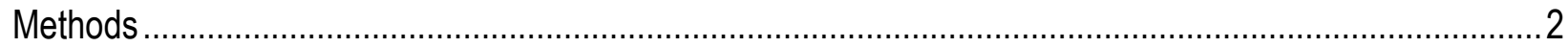

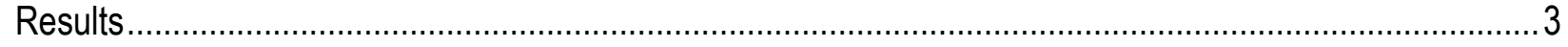

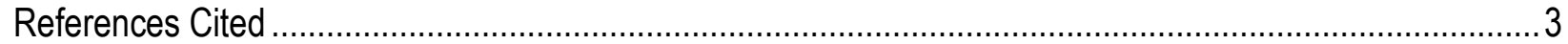


This page left intentionally blank 


\title{
Compilation and Analysis of Multiple Groundwater-Quality Datasets for Idaho
}

\author{
By Stephen A. Hundt and Candice B. Hopkins
}

\begin{abstract}
Groundwater is an important source of drinking and irrigation water throughout Idaho, and groundwater quality is monitored by various Federal, State, and local agencies. The historical, multiagency records of groundwater quality include a valuable dataset that has yet to be compiled or analyzed on a statewide level. The purpose of this study is to combine groundwater-quality data from multiple sources into a single database, to summarize this dataset, and to perform bulk analyses to reveal spatial and temporal patterns of water quality throughout Idaho. Data were retrieved from the Water Quality Portal (https://www.waterqualitydata.us/), the Idaho Department of Environmental Quality, and the Idaho Department of Water Resources. Analyses included counting the number of times a sample location had concentrations above Maximum Contaminant Levels (MCL), performing trends tests, and calculating correlations between water-quality analytes. The water-quality database and the analysis results are available through USGS ScienceBase (https://doi.org/10.5066/F72V2FBG).
\end{abstract}

\section{Introduction}

Groundwater is a vital resource to Idaho, and is the primary source of drinking water for as much as 95 percent of Idaho's citizens. Groundwater also is essential for irrigation, industry, and to provide base flow to streams and rivers. Groundwater quality is measured by various agencies for an array of purposes, yet trends in the quality of groundwater over time are rarely analyzed on a large scale for various analytes. Scientists and managers would greatly benefit from a better understanding of how concentrations of constituents of concern are correlated with each other, and how they have changed over time.

Groundwater quality has been tested by Federal, State, and local agencies in Idaho for various purposes. These data have been used on their own or as part of a project, but only a few studies have addressed temporal evaluation of statewide groundwater quality for Idaho, and those studies have focused only on nitrate as a contaminant of concern. Nitrate is commonly elevated in groundwater in Idaho and trends in nitrate concentrations have been monitored by various agencies (Parliman, 2002; Neely, 2013). Localized groundwater degradation due to high nitrate concentrations has been observed in several areas of the state, and has led to the establishment of Nitrate Priority Areas by the Idaho Department of Environmental Quality. Although nitrate has been identified as a groundwater contaminant, it is unclear how nitrate concentrations have changed in recent years, and if other constituents may be elevated in areas with high nitrate concentrations. Other constituents are not comprehensively analyzed to detect the presence and trends of degraded groundwater quality. 
A comprehensive evaluation of the quality and trends of various groundwater constituents based on historical data is needed for Idaho. An integrated dataset consisting of data from several Idaho State, Federal, and local agencies, as proposed in this study, will improve delineation of temporal trends and correlated contaminant concentrations, and will help managers allocate resources for maintaining highquality water from public-supply wells. The insights gained from this evaluation will be used to help better understand water resources, and may help guide groundwater monitoring in the future.

This report contains a file of a slide presentation given to the Idaho Department of Environmental Quality on July 6, 2017, in Boise, Idaho. The material summarizes the temporal trends in the quality of groundwater used or potentially used for drinking-water supplies in Idaho, nitrate concentrations in areas of elevated concentrations, and the examination of other constituents that may be of concern to human health. A secondary objective was to assemble an integrated dataset of groundwater-quality data within Nitrate Priority Areas.

\section{Methods}

Groundwater-quality data for all constituents that have a drinking-water maximum contaminant level (MCL) or secondary MCL (SMCL) were analyzed for the entire State of Idaho. Data sources included were collected from the Idaho Department of Water Resources, Idaho Department of Environmental Quality, U.S. Geological Survey, counties, and other monitoring agencies. Historical data from as far back as the 1920s were considered for use in this study.

The groundwater quality data retrieved from multiple agencies were compiled into a database useful for analyzing groundwater quality, water-quality trends, and other pertinent factors (such as well characteristics and aquifer type). Data were combined, duplicates were removed, and minor additional edits were made to unify their content.

The data were imported into the R programming language for analysis. Summary statistics were computed to describe the scope of groundwater-quality data collected in the state of Idaho over the past century. The number and locations of wells, the number of analytes collected, and the patterns of data collected over time were described.

Additional analysis revealed the presence and spatial distribution of degraded water quality, trends in analyte concentrations, and correlation among analytes. The number of MCL exceedances at every sampled well were counted for all analytes with an MCL. Kendall trend tests were performed and Sen-Theil slopes were calculated to document changes in concentrations of analytes over time. Techniques to handle censored data (reported as a " $<$ " or less than a reporting limit) with multiple reporting limits were used (Helsel and Hirsch, 2002; Antweiler and Taylor, 2008). The presence and strength of correlations among analyses were explored by calculating the Spearman correlation coefficients. The compiled database and analysis results are available in Hundt and others (2018). 


\section{Results}

The compiled database contains more than 1.9 million unique records from more than 16,000 wells spanning the years 1920 to 2016 . The analysis results include:

- Counts of total samples collected since 1990 for each sampling location and the number of times each analyte exceeded the $2017 \mathrm{MCL}$.

- Kendall trend coefficients, $p$-values, and Sen-Theil slopes for every sampling location for any analyte that was sampled at least four times since 1990.

- Spearman correlation coefficients for all pairs of analytes.

The water-quality database and the analysis results are available through USGS ScienceBase (https://doi.org/10.5066/F72V2FBG). Further detail on the results of this study is shown in the accompanying slide presentation.

\section{References Cited}

Antweiler, R.C., and Taylor, H.E., 2008, Evaluation of statistical treatments of left-censored environmental data using coincident uncensored data sets-I. Summary statistics: Environmental Science \& Technology, v. 42, no. 10, p. 3732-3738, https://doi.org/10.1021/es071301c.

Helsel, D.R., and Hirsch, R.M., 2002, Statistical methods in Water Resources: U.S. Geological Survey Techniques of Water-Resources Investigations, book 4, chap. A3, 522 p.

Hundt, S.A., Hopkins, C.B., and Tefler, L., 2018, Compiled database and results of the analysis of multiple groundwater-quality datasets for Idaho: U.S. Geological Survey data release, https://doi.org/10.5066/F72V2FBG.

Idaho Department of Environmental Quality, 2014, 2014 Nitrate Priority Area delineation and ranking process: Idaho Department of Environmental Quality, 128 p., accessed September 2016, at http://www.deq.idaho.gov/media/1117845/nitrate-priority-area-delineation-ranking-2014.pdf.

Lee, L., 2017, Package 'NADA': Nondetects and data analysis for environmental data, version 1.6-1: https://cran.r-project.org/web/packages/NADA/NADA.pdf.

Neely, K.W., 2013, Trend analyses for Idaho's Nitrate Priority Areas, 2002-2011: Water Information Bulletin, No. 50, Part 8.

Parliman, D.J., 2002, Analysis of nitrate $\left(\mathrm{NO}_{3}-\mathrm{N}\right)$ concentration trends in 25 ground-water-quality management areas, Idaho, 1961-2001: U.S. Geological Survey Water-Resources Investigations Report 2002-4056, 60 p.

U.S. Environmental Protection Agency, 2017, National Primary Drinking Water Regulations: U.S. Environmental Protection Agency website, accessed May 2017, at https:/www.epa.gov/groundwater-and-drinking-water/national-primary-drinking-water-regulations. 

Publishing support provided by the U.S. Geological Survey Science Publishing Network, Tacoma Publishing Service Center

For more information concerning the research in this report, contact the Director, Idaho Water Science Center

U.S. Geological Survey

230 Collins Road

Boise, Idaho 83702

http://id.water.usgs.gov 
